\title{
In Memoriam: John J. Kavanagh (1947-2021)
}

It is with great sadness that we announce the passing of Dr. John Joseph Kavanagh (March 25, 2021). He graduated from Sidney Kimmel Medical College at Thomas Jefferson University in 1975. After, Dr. Kavanagh completed a residency in internal medicine at the Medical University of South Carolina in 1978 and subsequently did his Hematology Fellowship at the University of Texas Health Science Center in Houston, Texas. He will be remembered as an outstanding leader in the field of gynecologic oncology and has left a legacy as a devoted mentor and teacher to so many who care for women's cancer. Dr. Kavanagh had a distinguished career as a medical oncologist who focused his work on the treatment of women with gynecologic cancers. He spent over 40 years of his academic career at MD Anderson Cancer Center and subsequently continued his work at Chulalongkorn University in Bangkok, Thailand where he held the role of International Faculty.

As a clinician, he was a superb and astute individual who always looked beyond the recognized standard options with a focus on the patient as an individual. Personally, I remember how thoughtful and thorough Dr. Kavanagh was in his approach to treating his patients. He always asked the questions often missed by others and seemed to always find a new option for the patient. His patients and their families loved him, as he took the time to discuss all avenues available to the patient and answered questions regardless of how long it took to satisfy patient's concerns.

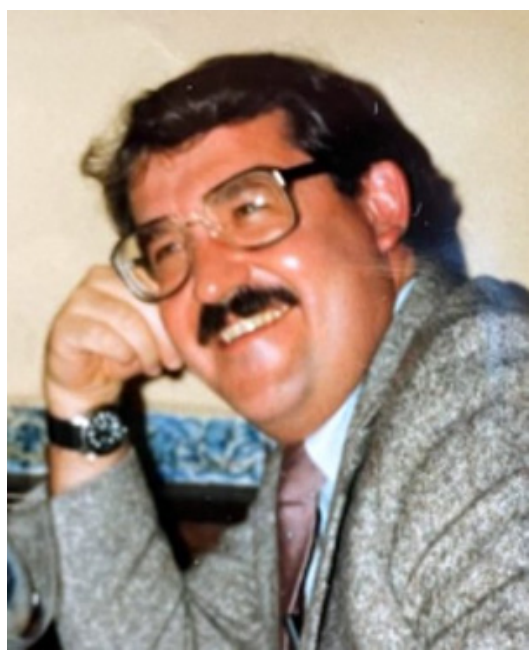

He was an outstanding mentor and was always surrounded by visitors from all corners of the world. These physicians always spoke very highly of his capacity to explain in detail even the most complex of subjects in a way that was easy to understand with profound insight and fund of knowledge of the literature.

Dr. Kavanagh served as Editor-in-Chief of the International Journal of Gynecological Cancer from 2001 to 2008. He also served as Member of the Steering Committee, Council Member, Chair of the Membership Committee, and Member of the Guidelines and Informatics Committee for the International Gynecologic Cancer Society.

The field of gynecologic oncology has lost one of its 'giants' and we will truly miss his talent, his contributions, and most of all his engaging and warm personality.

\section{Pedro T Ramirez}

Correspondence to Dr Pedro T Ramirez, Department of Gynecologic Oncology and Reproductive Medicine, MD Anderson Cancer Center, Houston, Texas, USA; peramire@mdanderson.org

Twitter Pedro T Ramirez @pedroramirezMD Contributors Dr PTR is the sole contributor.

Funding The authors have not declared a specific grant for this research from any funding agency in the public, commercial, or not-for-profit sectors.

Competing interests None declared.

Patient consent for publication Not required.

Provenance and peer review Not commissioned; internally peer reviewed.

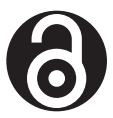

\section{OPEN ACCESS}

Open access This is an open access article distributed in accordance with the Creative Commons Attribution Non Commercial (CC BY-NC 4.0) license, which permits others to distribute, remix, adapt, build upon this work non-commercially, and license their derivative works on different terms, provided the original work is properly cited, an indication of whether changes were made, and the use is non-commercial. See: http://creativecommons.org/ licenses/by-nc/4.0/.

C IGCS and ESGO 2021. Re-use permitted under CC BY-NC. No commercial re-use. Published by BMJ.

$$
\text { D) Check for updates }
$$

To cite Ramirez PT. Int J Gynecol Cancer 2021;31:1310.

Accepted 30 June 2021

Published Online First 13 July 2021

Int J Gynecol Cancer 2021;31:1310. doi:10.1136/ijgc-2021-002907 